\title{
THE VALUE OF HUMAN DIGNITY IN INTERPRETING SOCIO- ECONOMIC RIGHTS
}

\author{
SANDRA LIEBENBERG*
}

\begin{abstract}
There has been considerable criticism of the use of human dignity as a guiding value in the context of South Africa's equality jurisprudence. What are the implications of the use of the value in socio-economic rights jurisprudence? Drawing on the work of Martha Nussbaum, the article links the value of human dignity to the material conditions necessary to enable people to develop and exercise their capabilities. Access to basic social services is crucial not only to people's physical survival, but also to enable the development of their potential to shape their own lives and to be active agents in the shaping of our new society. Human dignity as a relational concept requires society to respect the equal worth of the poor by marshalling its resources to redress the conditions that perpetuate their marginalisation. This, in turn, requires a focus on the actual impact of the state's actions or omissions on the life chances of disadvantaged groups, and a response that is proportionate to the seriousness of that impact. In constitutional adjudication, it requires that a high burden of justification is placed on the state in cases involving a deprivation of basic human needs. The article concludes by examining how the Constitutional Court's reasonableness review standard and remedial jurisprudence could be strengthened to accord greater value to this conception of human dignity.
\end{abstract}

\section{INTRODUCTION}

Without the ability to secure the immediate needs of the present, the future is little more than a far-off possibility, remote both in perception and in reality. ${ }^{1}$

The inclusion of socio-economic rights as justiciable rights in the South African Bill of Rights affirms the critical importance of material conditions to human survival and development. ${ }^{2}$ In their seminal article,

* HF Oppenheimer Chair in Human Rights Law, University of Stellenbosch. Earlier versions of this paper were read at the SAJHR conference 'Twenty Years of Human Rights Scholarship and Ten Years of Democracy' (5-7 July 2004), and at the Stellenbosch Institute for Advanced Study (STIAS) seminar on 'Theories of Social and Economic Justice' (30-31 July 2004). Participants at both these events provided valuable comments and suggestions, for which I am indebted. I am also grateful for the comments and insights of my colleagues, André van der Walt and Lourens du Plessis, as well as the suggestions received from the SAJHR editors. Finally, I would like to thank Beth Goldblatt for challenging me to think critically about the limits of human dignity in advancing a transformative constitutional jurisprudence.

1 Arbour J in Gosselin v Québec (Attorney General) 2002 SCC 84, 392.

2 The Preamble to the Constitution of the Republic of South Africa Act 108 of 1996 (1996 Constitution') proclaims that the Constitution was adopted with the purpose (amongst others) to '[i]mprove the quality of life of all citizens and free the potential of each person'. 


\section{arguing for the constitutional protection of socio-economic rights in South Africa, Craig Scott and Patrick Maklem argued as follows:}

Perhaps the strongest reason for including a certain number of economic and social rights is that by constitutionalising half of the human rights equation, South Africans would be constitutionalising only part of what it is to be a full person. A constitution containing only civil and political rights projects an image of truncated humanity. Symbolically, but still brutally it excludes those segments of society for whom autonomy means little without the necessities of life. ${ }^{3}$

Socio-economic rights are not valued as commodities, but because of what they enable human beings to do and to be. ${ }^{4}$ If basic subsistence needs are not met, humans face severe threats to life and health. But, in addition, such deprivation impedes the development of a whole range of human capabilities, including the ability to fulfil life plans and participate effectively in political, economic and social life. ${ }^{5}$ It also deprives society

3 C Scott \& P Macklem 'Constitutional Ropes of Sand or Justiciable Guarantees? Social Rights in a New South African Constitution' (1992) 141 Univ of Pennsylvania LR 1, 29.

4 Martha Nussbaum has provided an influential philosophical justification for constitutional principles aimed at ensuring the conditions for the development and exercise of human capabilities. See particularly MC Nussbaum Women and Human Development - The Capabilities Approach (2000) (hereafter 'Women and Human Development'). Her approach focuses 'on human capabilities, that is, what people are actually able to do and to be - in a way informed by an intuitive idea of a life that is worthy of the dignity of the human being'. (5) On the relationship between capabilities and human rights, see Women and Human Development 96-101 and Nussbaum 'Capabilities, Human Rights and the Universal Declaration' in BH Weston \& SP Marks (eds) The Future of International Human Rights (1999) 25-64. In development economics, the capabilities approach to quality of life assessments was pioneered by Amartya Sen in a range of works, including his collaboration of the Human Development Reports of the United Nations Development Programme (UNDP). See, for example, 'Equality of What' in A Sen Choice, Welfare and Measurement (1982) 353-369 and his recent work, Development as Freedom (2001). For Sen, the goal of development should be to expand the capabilities of persons 'to lead the kind of lives they value - and have reason to value' (Development as Freedom 18). Nussbaum discusses the differences between her and Sen's 'capabilities' theory in Women and Human Development 11-15. However, both view the 'capabilities' approach as more appropriate to quality of life assessments in human development than many of the traditional alternatives. Nussbaum discusses the defects of standard approaches such as Gross National Product (GNP) per capita, utilitarian approaches (which ask about the total or average utility of the population, as measured by expressions of satisfaction), and approaches focusing on basic resource distribution in Women and Human Development 59-70.

5 For an account of the impact and experience of poverty in South Africa, see J May Poverty and Inequality in South Africa: Report Prepared for the Office of the Executive Deputy President and the Inter-Ministerial Committee for Poverty and Inequality (PIR Report) (1998). See particularly the experiences of poverty documented by The South African Participatory Poverty Assessment: 'The Experience and Perceptions of Poverty' Data Research Africa Report (SAPPA) cited on 3-5 of the PIR Report. These include: alienation from the community, emotional stress and anxiety, food insecurity, the impact of time-consuming domestic tasks, particularly for poor women, overcrowded living conditions with the associated loss of privacy, and an increased exposure to violence. The impact on people's life chances of a lack of access to basic services and productive resources such as land is vividly illustrated in the Report of the National 'Speak Out on Poverty' Hearings convened by the Commission for Gender Equality, the South African Human Rights Commission and the South African NGO Coalition from March to June 1998: see D Budlender The People's Voices (1998). 
of the contributions of all its members. ${ }^{6}$ Thus both the individual and society are impoverished by our collective failure to ensure living conditions worthy of the dignity of people as both individual and social beings. ${ }^{7}$

As justiciable rights, socio-economic rights must be interpreted in the context of concrete cases. The courts must determine how much must be provided, to whom, at what pace and in what order of priority. In order to do so, they must explicate the underlying values that guide the interpretation of these rights. In so doing, the courts also affirm the values constituting our post-apartheid society. ${ }^{8}$

Human dignity as a right and value has played a central role in the Constitutional Court's human rights jurisprudence. ${ }^{9}$ The Court has also invoked dignity as the central value informing its approach to the interpretation of socio-economic rights, particularly the reasonableness standard of review for the positive duties imposed by these rights. ${ }^{10}$ Thus Yacoob J stated in Grootboom:

It is fundamental to an evaluation of the reasonableness of state action that account be taken of the inherent dignity of human beings. The Constitution will be worth infinitely less than its paper if the reasonableness of state action concerned with housing is determined without regard to the fundamental constitutional value of human dignity. Section 26, read in the context of the Bill of Rights as a whole, must mean that the

6 Sen expresses this reciprocal relationship as follows: 'These capabilities can be enhanced by public policy, but also, on the other side, the direction of public policy can be influenced by the effective use of participatory capabilities by the public.' Development as Freedom (note 4 above) 18.

7 Jennifer Nedelsky describes human beings 'as both essentially individual and essentially social creatures'. 'Reconceiving Rights as Relationship' (1993) 1 Review of Constitutional Studies 1, 8. In National Coalition for Gay \& Lesbian Equality v Minister of Justice 1999 (1) SA 6 (CC) Sachs J refers to the constitutional recognition of the associational dimensions of human life as follows: 'While recognising the unique worth of each person, the Constitution does not presuppose that a holder of rights is an isolated, lonely and abstract figure possessing a disembodied and socially disconnected self. It acknowledges that people live in their bodies, their communities, their cultures, their places and their times.' (para 117). See also Bernstein v Bester 1996 (2) SA 751 (CC) para 67.

8 In Dawood v Minister of Home Affairs 2000 (3) SA 936 (CC) para 35 O'Regan J described the role of the constitutional value of human dignity in constituting post-apartheid society: 'The Constitution asserts dignity to contradict our past in which human dignity for black South Africans was routinely and cruelly denied. It asserts it too to inform the future, to invest in our democracy respect for the intrinsic worth of all human beings.'

9 In Dawood (ibid) para 35 the Constitutional Court held that the value of human dignity 'is a value that informs the interpretation of many, possibly all, other rights'. See, for example, S v Makwanyane 1995 (3) SA 391 (CC) para 144 (Chaskalson P) and para 328 (O'Regan J) (death penalty); August v Electoral Commission 1999 (3) SA 1 (CC) para 16 (Sachs J) (right to vote); and the range of equality cases in which dignity is a central factor in identifying 'unfair' discrimination: for example Harksen v Lane NO 1998 (1) SA 300 (CC) paras 50-51; National Coalition for Gay and Lesbian Equality $v$ Minister of Justice (note 7 above) paras 15-28 (Ackermann J) and paras 120-129 (Sachs J).

10 Government of the Republic of South Africa v Grootboom 2001 (1) SA 46 (CC) paras 38, 41. 
respondents have a right to reasonable action by the state in all circumstances and with particular regard to human dignity. In short, I emphasise that human beings are required to be treated as human beings. ${ }^{11}$

This article explores the value of human dignity in interpreting socioeconomic rights. ${ }^{12}$ My focus is primarily on the positive duties imposed on these rights to facilitate and provide access to social benefits. ${ }^{13}$ I examine the critiques of human dignity as a guiding value in the context of South Africa's equality jurisprudence. In response to these critiques I explore traditions in the interpretation of human dignity that can make a positive contribution to our evolving jurisprudence on socio-economic rights.

By focusing on human dignity, I am not claiming that dignity is the only value that explicates our commitment to socio-economic rights. ${ }^{14}$ There is an important body of literature that explores the significance of a number of other values in relation to socio-economic rights. ${ }^{15}$ The core

11 Ibid para 83. On the relationship between human dignity as an independent right, the other rights specifically entrenched in the Bill of Rights and the value of human dignity, see Dawood (note 8 above) para 35 .

12 On the relationship between human dignity as an independent right, the other rights specifically entrenched in the Bill of Rights, and the value of human dignity, see Dawood (note 8 above) para 35; Jaftha $v$ Schoeman 2005 (1) BCLR 78 (CC) para 21.

13 Section 7(2) of the Constitution places an overarching duty on the State 'to respect, protect, promote and fulfil' the rights in the Bill of Rights. This signals that the rights in the Bill of Rights impose a combination of negative and positive duties. For a discussion of these duties in the context of socio-economic rights, see S Liebenberg 'The Interpretation of SocioEconomic Rights' in S Woolman et al (eds) Constitutional Law of South Africa 2ed (2004) 33-6 - 33-7; See also The Social and Economic Rights Action Centre and the Centre for Economic and Social Rights v Nigeria Communication No 155/96 October 2001, African Commission on Human and Peoples' Rights paras 44 - 47 (available at <http://wwwserver.law.wits.ac.za/ humanrts/africa/comcases/155-96.html $>$ ).

14 The Constitutional Court has affirmed that all three foundational constitutional values are implicated in a denial of socio-economic rights: "All the rights in our Bill of Rights are interrelated and mutually supporting. There can be no doubt that human dignity, freedom and equality, the foundational values of our society, are denied those who have no food, clothing or shelter. Affording socio-economic rights to all people therefore enables them to enjoy the other rights enshrined in Chapter 2. The realisation of these rights is also key to the advancement of race and gender equality and the evolution of a society in which men and women are equally able to achieve their full potential.' Grootboom (note 10 above) para 23. See also Soobramoney v Minister of Health, Kwa-Zulu-Natal 1998 (1) SA 765 (CC) para 8.

15 See, for example, N Haysom 'Constitutionalism, Majoritarian Democracy and SocioEconomic Rights' (1992) 2 SAJHR 451 (a basic floor of socio-economic rights is required to guarantee a minimum degree of civic and political participation); For a similar argument in the US context, see: FI Michelman 'Welfare Rights in a Constitutional Democracy' (1979) 3 Washington Univ LQ 659 (socio-economic rights are necessary prerequisites of effective participation in representative democracy); P de Vos 'Grootboom, The Right of Access to Housing and Substantive Equality as Contextual Fairness' (2001) 17 SAJHR 258 (the right to equality and socio-economic rights are 'two sides of the same coin' in that they seek to achieve '. . a specific contextual form of equality as the realisation of particular social and economic rights', 263, 265). For a discussion of the shortcomings and theoretical limitations of an equality-based theoretical justification of socio-economic rights, see A van der Walt 'A South African Reading of Frank Michelman's Theory of Social Justice' in H Botha et al (eds) Rights and Democracy in a Transformative Constitution (2004) 163, 174-9. Nonetheless, as this paper illustrates, there are important insights in equality jurisprudence regarding the application of human dignity to adjudicate the constitutionality of people's exclusion from social benefits. 
foundational values of human dignity, freedom and equality are in any event highly interrelated. ${ }^{16}$ I focus on human dignity because of the important role it has played in the Constitutional Court's human rights jurisprudence in general, and because its role in the interpretation of socio-economic rights has been relatively unexplored. I also seek to develop a concept of human dignity that can help identify deficiencies in the Court's current socio-economic rights jurisprudence and illuminate how the jurisprudence should be developed to constitute a stronger response to socio-economic deprivation.

\section{Critiques of Dignity as a Value in Constitutional Adjudication}

There have been several critiques of human dignity as a guiding value in constitutional adjudication, particularly in relation to equality jurisprudence and the test for unfair discrimination. ${ }^{17}$ However, these critiques are also relevant to human dignity as a guiding value in socio-economic rights jurisprudence and for this reason they require careful consideration here.

Three major critiques of dignity as a value in human rights adjudication have been articulated. The first relates to the alleged indeterminacy of human dignity as a normative concept. Thus it has been argued that dignity is too vague and multifaceted a concept to serve us well as a guiding value in equality jurisprudence. ${ }^{18}$ The second critique asserts that human dignity as a value is irrevocably linked with the protection of freedom and autonomy. As such, it serves to discourage the positive, redistributive measures needed to remedy conditions such as material inequality and disadvantage. ${ }^{19}$ Cathi Albertyn and Beth Goldblatt have most forcefully articulated a third critique (which is closely related to the second) in the context of equality jurisprudence. They argue that the reliance on the value of dignity in the test for unfair discrimination promotes a narrow focus on individual personality issues as opposed to 'a group-based understanding of material advantage and

16 Kriegler J refers to human dignity, equality and freedom as 'conjoined, reciprocal and covalent values' which are 'foundational' to South Africa: $S$ v Mamabolo 2001 (3) SA 409 (CC) para 41.

17 The Constitutional Court's approach to $\mathrm{s} 9$ of the Constitution is set out in Harksen (note 9 above) paras 50-53. Dignity plays an important role in both the identification of unlisted prohibited grounds of discrimination and the factors for determining whether the discrimination is unfair: Harksen paras 49 and 51.

18 For example, Davis alludes to the 'multifaceted meanings' of dignity, and argues that the Court 'has given dignity both a content and scope that make for a piece of jurisprudential Legoland - to be used in whatever form and shape is required by the demands of the judicial designer'. D Davis 'Equality: The Majesty of Legoland Jurisprudence' (1999) 116 SALJ 398, 413. See also D Davis Democracy and Deliberation (1999) 69-95.

19 This critique is discussed by Susie Cowen in her article defending the use of the value of human dignity in South African's equality jurisprudence: 'Can "Dignity" Guide South Africa's Equality Jurisprudence' (2001) 17 SAJHR 34, 51-8. 
disadvantage'. ${ }^{20}$ It could result in 'an individualised and abstract conception of equality divorced from actual social and economic disadvantage. ${ }^{21}$ Thus the need to redress systemic patterns of inequality and disadvantage are obscured by focusing on individual personality issues related to subjective feelings of self-respect and self-worth.

If dignity as a value is inextricably aligned with negative liberty and individual personality issues, it will be inimical to the development of a transformative socio-economic rights jurisprudence. In the next section I will develop an argument that there are positive traditions associated with the interpretation of human dignity that can add value to our socioeconomic rights jurisprudence. In so doing, I am not seeking to deny the dangers of a regressive deployment of human dignity in the interpretation of rights such as equality, and indeed, socio-economic rights. Certainly, I believe that there is a case to be made that the Constitutional Court has not engaged sufficiently with the value of equality in its s 9 jurisprudence. ${ }^{22}$ My concern is to examine how the value of human dignity can enrich, rather than impoverish, our evolving jurisprudence on socioeconomic rights.

\section{Human Dignity as a Value}

Dignity has deep roots in Kantian moral philosophy that affirms the inherent worth of human beings. According to the Kantian imperative human beings should be treated 'never simply as a means, but always at the same time as an end'. ${ }^{23}$ In other words, we should relate to each other as having intrinsic worth as human beings. O'Regan $\mathbf{J}$ affirms this notion of human dignity as follows:

20 C Albertyn \& B Goldblatt 'Facing the Challenge of Transformation: Difficulties in the Development of an Indigenous Jurisprudence of Equality' (1998) 14 SAJHR 248, 257-258, 272. Similar arguments in support of the development of a more substantive approach to equality were made by the Centre for Applied Legal Studies in their amicus intervention in National Coalition (note 7 above): see paras 58-64 (Ackermann J) and paras 120-129 (Sachs J).

21 C Albertyn 'Equality' in M H Cheadle et al (eds) South African Constitutional Law: The Bill of Rights (2002) 51, 60.

22 Albertyn (ibid ) attributes this reluctance, at least partially, to the Court's discomfort with the notion that 'the value of equality encompasses an idea of material equality and economic redistribution.' She argues that this 'redistributive function sits uncomfortably with the institutional role of courts and with the distinction the courts seek to draw between issues of social policy and issues of law' (64-5); See also D Davis 'Legoland Jurisprudence' (note 18 above) 413-414. For a recent consideration by the Constitutional Court of the value of equality in the context of s 9 and the positive duties it imposes on the state, see Minister of Finance $v$ Van Heerden 2004 (6) SA 121 (CC) paras 22-27.

23 I Kant The Moral Law: Kant's Groundwork of the Metaphysic of Morals (1963) (trans H J Patron) 96, cited and discussed in D Meyerson Rights Limited (1997) 12-13. See also the discussion of the Kantian imperative and concept of human dignity by L Ackermann 'Equality and the South African Constitution: The Role of Dignity' (2000) 60 Heidelberg Journal of Int $L$ 537, 540-2. 
The importance of dignity as a founding value of our new Constitution cannot be overemphasised. Recognising a right to dignity is an acknowledgment of the intrinsic worth of human beings: human beings are entitled to be treated as worthy of respect and concern. ${ }^{24}$

Human dignity is closely related to the notion of human beings as agents capable of making moral choices, of shaping our identity, resisting injustice and participating in the shaping of society. ${ }^{25}$ Martha Nussbaum expresses this notion thus:

The core idea is that of the human being as a dignified free being who shapes his or her own life in cooperation and reciprocity with others, rather than being passively shaped or pushed around by the world in the manner of a 'flock' or 'herd' animal. A life that is really human is one that is shaped throughout by these human powers of practical reason and sociability. ${ }^{26}$

Thus, to value the inherent dignity of human beings as a society is to ensure that people enjoy civil and political liberties and also have effective access to the social and economic means indispensable to the development of their physical, emotional, creative and associational capabilities. Nussbaum develops a provisional list of 'central human capabilities' that should be secured in political and constitutional principles as a basic social minimum for all. Through this list she seeks to isolate 'those human capabilities that can be convincingly argued to be of central

24 Makwanyane (note 9 above) para 328 (emphasis added). See also the comments of Ackermann $\mathbf{J}$ in National Coalition (note 7 above): 'Dignity is a difficult concept to capture in precise terms. At its least, it is clear that the constitutional protection of dignity requires us to acknowledge the value and worth of all individuals as members of society.' (para 29).

25 In the context of evictions, the Constitutional Court has recently highlighted the importance of mediation and serious consideration of the need of occupiers for suitable alternative land in considering whether an eviction is 'just and equitable' in terms of the Prevention of Illegal Eviction from and Unlawful Occupation of Land Act 19 of 1998 (PIE). Sachs J referred to the importance of mutual respect for people's agency in the following terms: 'Thus those seeking eviction should not be encouraged to rely on concepts of faceless and anonymous squatters automatically to be expelled as obnoxious social nuisances. Such a stereotypical approach has no place in the society envisaged by the Constitution; justice and equity require that everyone is to be treated as an individual bearer of rights entitled to respect for his or her dignity. At the same time those who find themselves compelled by poverty and landlessness to live in shacks on the land of others, should be discouraged from regarding themselves as helpless victims, lacking the possibility of personal moral agency.' Port Elizabeth Municipality $v$ Various Occupiers 2005 (1) SA 217 (CC) para 41.

26 Women and Human Development (note 3 above) 72 (footnotes omitted). Nussbaum's notion of 'a life that is really human' has been criticised on the basis that an attempt to elaborate the conditions of a fully human life implies that those who are denied these conditions, have lost their dignity, and are no longer 'dignified': see D Cornell 'A Call for a Nuanced Constitutional Jurisprudence: Ubuntu, Dignity and Reconciliation' paper presented at a New Social Forms Seminar organised by the Department of Sociology and Social Anthropology, Stellenbosch University, 23 July 2004 (available at < www.sun.ac.za/sociology/activities_nsf.htm >). My own reading of Nussbaum is that she does not claim that poverty deprives people of their dignity, but rather that society fails to respect the dignity of people by neglecting to create the conditions under which people's capabilities can develop and be effectively exercised. As she puts it: 'We begin, then, with a sense of the worth and dignity of basic human powers, thinking of them as claims to a chance for functioning, claims that give rise to correlated social and political duties.' Women and Human Development (note 4 above) 84 . See further the discussion at $84-86$. 
importance in any human life, whatever else the person pursues or chooses'. ${ }^{27}$ She argues that that they have a 'special claim to be supported for political purposes in a pluralistic society' because of their importance in making any choice of a way of life possible. ${ }^{28}$ Nussbaum's project of developing a list of 'central human capabilities' has been criticised for being reductive and insufficiently sensitive to human difference, complexity and freedom. ${ }^{29}$ A valuable feature of the list is its holistic portrayal of human life. It illustrates that access to socio-economic rights is not simply a matter of bare survival, but also includes the development and exercise of the people's associational, intellectual and emotional capabilities. In any event, I do not believe that it is necessary to subscribe to her list (or even her project of compiling a list) to support the central idea that we show respect for human potential and agency by creating an environment of basic liberties and material support which enables them to flourish. ${ }^{30}$

In his analysis of human dignity as a normative concept, Oscar Schachter distinguishes between 'the subjective aspect of human dignity (how one feels or thinks about another) and the objective aspect (how one treats another), ${ }^{31}$ In its objective, social dimension, he argues that human dignity 'requires recognition of a minimal concept of distributive justice that would require satisfaction of the essential needs of everyone'. ${ }^{32}$ Thus he includes in his list of conduct and ideas that offend or denigrate the worth and dignity of individuals, '[d]egrading living

27 Women and Human Development (note 4 above) 74. Nussbaum's list of central human functional capabilities relates to the following dimensions of human existence: life; health; bodily integrity; the senses, imagination and thought; emotions, practical reason, affiliation; other species; play; political and material control over one's environment (77-80).

28 Women and Human Development (note 4 above) 75.

29 See K Van Marle “"The Capabilities Approach”, “The Imaginary Domain”, and "Asymmetrical Reciprocity"': Feminist Perspectives on Equality and Justice' (2003) 11 Feminist Legal Studies 255-78, particularly the discussion at 272-3. Sen's reservations about the search for a list of central human capabilities relates to the difficulty in seeing how the exact lists and weights would be chosen without appropriate specification of the context of their use (which could vary), but also from a disinclination to accept any substantive diminution of the domain of public reasoning'. For Sen the framework of human capabilities is important for clarifying and illuminating 'the subject matter of public reasoning ... It does not - and cannot - displace the need for public reasoning.' A Sen 'Elements of a Theory of Human Rights' (2004) 32 Philosophy \& Public Affairs 315-356.

30 Nussbaum herself emphasises that the list 'remains open-ended and humble; it can always be contested and remade'. It aims at 'multiple realisability', leaving room for more concrete specification according to local beliefs and circumstances. Women and Human Development (note 4 above) 77.

31 O Schachter 'Human Dignity as a Normative Concept' (1983) 77 Am J of Int Law 848, 849.

32 Ibid 851. David Feldman makes the following observations in relation to the subjective and objective dimensions of human dignity: 'In relation to the subjective aspect of dignity, the law of human rights will typically be concerned to prevent treatment which damages a person's self-respect and physical or moral integrity. With regard to the objective aspect, the law will usually have to go further, imposing positive duties on people to act in ways which optimise the conditions for social respect and dignity: 'Human Dignity as a Value - Part I' (1999) Winter Public Law 682, 686-7. 
conditions and deprivation of basic needs'. ${ }^{33}$ International human rights law derives both civil and political rights as well as social, economic and cultural rights from the value of human dignity. ${ }^{34}$ The Constitutional Court has also referred on a number of occasions to the disjuncture between our founding constitutional values and conditions of material deprivation. ${ }^{35}$

These approaches to human dignity illustrate that its ambit is by no means confined to subjective personality issues. On the contrary, respect for human dignity requires that we pay close attention to conditions of material disadvantage and its impact on different groups in our society.

This brings us to the concern that human dignity is irrevocably connected with negative liberty. Accordingly, dignity as a value would support constraints on state interference with individual liberties, and would discourage intervention to redistribute social resources. Human dignity undeniably requires respect for personal autonomy and choices. ${ }^{36}$ But at the same time our commitment to respect for each person's substantive freedom and life choices requires the creation of the social conditions on which people's capacity for personal fulfilment and agency depend. This leads David Feldman to describe dignity as a 'two-edged sword', which can operate both to uphold and restrict personal liberties:

33 Schachter (note 31 above) 852 .

34 The preambles of both the International Covenant on Economic, Social, and Cultural Rights (1966) and the International Covenant on Civil and Political Rights (1966) recognise that the rights contained in the respective Covenants 'derive from the inherent dignity of the human person'. In Social and Economic Rights Action Center and the Center for Economic and Social Rights $v$ Nigeria (note 13 above) the African Commission on Human and Peoples' Rights derived a right to food from a number of other provisions in the African Charter on Human and Peoples' Rights. In particular, it held that the right to food is inseparably linked to the dignity of human beings and is therefore essential for the enjoyment and fulfilment of other rights as health, education, work and political participation'. (para 65).

35 In Soobramoney (note 14 above) paras 8-10 the Constitutional Court affirmed that the Constitution commits us to transform the intolerable conditions in which people live in order to vindicate the values of human dignity, equality and freedom. In Grootboom (note 10 above) para 2 the Court stated that the issues in the case remind us of the intolerable conditions under which many of our people are still living and brings home 'the harsh reality that the Constitution's promise of dignity and equality for all remains a distant dream'. See also A Chaskalson 'Human Dignity as a Foundational Value of our Constitutional Order' (2000) 16 SAJHR 193, 204 - 205.

36 The links between dignity and freedom are described in the following terms by Ackermann $\mathrm{J}$ in Ferreira v Levin NO 1996 (1) SA 984 (CC): 'Human dignity cannot be fully valued or respected unless individuals are able to develop their humanity, their "humanness" to the full extent of its potential. Each human being is uniquely talented. Part of the dignity of every human being is the fact and awareness of this uniqueness. An individual's human dignity cannot be fully respected or valued unless the individual is permitted to develop his or her talents optimally. Human dignity has little value without freedom; for without freedom personal development and fulfilment are not possible. Without freedom, human dignity is little more than an abstraction. Freedom and dignity are inseparably linked. To deny people their freedom is to deny them their dignity' (para 49). See also Prince v President, Cape Law Society 2002 (2) SA 794 (CC): 'Our society is diverse. . The protection of diversity is the hallmark of a free and open society. It is the recognition of the inherent dignity of all human beings. Freedom is an indispensable ingredient of human dignity' (Ngcobo J, para 49). 
[W] must not assume that the idea of dignity is inextricably linked to a liberalindividualistic view of human beings whose life-choices deserve respect. If the state takes a particular view of what is required for people to live dignified lives, it may introduce regulations to restrict the freedom which people have to make choices which, in the state's view, interfere with the dignity of the individual, a social group or the human race as a whole. ... The quest for human dignity may subvert rather than enhance choice and in some circumstances may limit rather than extend the scope of traditional 'first generation' human rights and fundamental freedoms. ${ }^{37}$

This may suggest that dignity is an indeterminate value - it cannot guide us as to when constraints should be placed on state interference with liberties and when it should require positive intervention. The capabilities approach to human dignity developed by Nussbaum provides us with at least one set of criteria for requiring positive state intervention. In Nussbaum's account, the state has a strong duty to guarantee the social basis of each person's basic human capabilities based on a principle of each person as an end. ${ }^{38}$ This fundamental commitment necessarily implies that the state is entitled to restrict the liberties of some members of society (provided this does not impinge on their basic human capabilities) in order to guarantee to everyone the social basis of basic human capabilities. ${ }^{39}$ In this sense, a focus on capabilities as social goals is also closely related to human equality. As Nussbaum explains:

[M]aking capabilities the goal entails promoting for all citizens a greater measure of material equality than exists in most societies, since we are unlikely to get all citizens above a minimum threshold of capability for truly human functioning without some redistributive policies. $^{40}$

Nussbaum's approach is compatible with a range of different theories about the degree of material equality that should be guaranteed in a just society from complete egalitarianism, a Rawlsian difference principle, and a focus on an ample social minimum for all. ${ }^{41}$ However, in most societies in the world, including South Africa, we are very far from

37 Feldman (note 32 above) 685.

38 Women and Human Development (note 4 above) 5-6, 89. In certain core areas of human functioning, 'a necessary condition of justice for a public political arrangement is that it delivers to citizens a certain basic level of capability' (71). She draws a distinction between capability and functioning, defending the former as the appropriate political goal given the value we attach to respecting people's choices. It is not the role of government to push people into 'functioning of the requisite sort' (87). She argues that 'for political purposes it is appropriate that we shoot for capabilities and those alone. Citizens must be left free to determine their own course after that. The person with plenty of food may always choose to fast, but there is a great difference between fasting and starving, and it is this difference that I wish to capture' (87).

39 In discussing socio-economic rights such as the right to shelter in terms of her capabilities approach, Nussbaum identifies the central focus as 'how people are actually enabled to live': 'Analyzing economic and material rights in terms of capabilities thus enables us to set forth clearly a rationale we have for spending unequal amounts of money on the disadvantaged, or creating special programs to assist their transition to full capability.' Women and Human Development (note 4 above) 99.

40 Ibid 86.

41 Ibid. 


\author{
providing even the basic minimum required to promote human \\ capabilities. $^{42}$
}

It is also helpful in this context to conceive of human dignity as a relational value. According to this notion we are interconnected beings. Our sense of self-worth, personal development and well-being is inextricably bound up with the extent to which we are valued by others and by the society at large. O'Regan $\mathbf{J}$ expresses this when she writes in Makwanyane that

the right to life was included in the Constitution not simply to enshrine the right to existence. It is not life as mere organic matter that the Constitution cherishes, but the right to human life: the right to live as a human being, to be part of a broader community, to share in the experience of humanity ... The right to life is more than existence, it is a right to be treated as a human being with dignity. ${ }^{43}$

To value human dignity is not to create zero-sum trade-offs between negative liberty and welfare, but to constitute positive social relationships which both respect autonomy and foster the conditions in which it can flourish. ${ }^{44}$ Dignity as a relational value can help us to perceive the limits of individual claims on social resources with reference to the needs and

42 See, further, ibid $12,86$.

43 Makwanyane (note 9 above) paras 326-7. In Soobramoney (note 14 above), the Court affirmed that having access to social goods and services were aspects of the right to '. . human life: the right to live as a human being, to be part of a broader community to share in the experience of humanity' (para 31). The associational dimensions of human dignity were also recently affirmed by the Supreme Court of Appeal in the decision of Minister of Home Affairs $v$ Watchenuka 2004 (4) SA 326 (SCA). The Court held that conditions imposed on refugees and asylum-seekers prohibiting them from undertaking employment and from studying constituted an infringement of their rights to human dignity and education. According to Nugent JA for the court: 'The freedom to engage in productive work - even where that is not required in order to survive - is indeed an important component of human dignity ... for mankind is pre-eminently a social species with an instinct for meaningful association. Self-esteem and the sense of self-worth - the fulfilment of what it is to be human is most often bound up with being accepted as socially useful' (para 27). It is important, however, not to associate the right to work only with productive, waged work. One of the major factors contributing to gender inequality is society's persistent undervaluing of reproductive work, of which women bear the disproportionate burden. See in this regard, President of the Republic of South African v Hugo 1997 (4) SA 1 (CC) para 38 (Goldstone J).

44 The relational conception of autonomy is described in the following terms by Jennifer Nedelsky: 'Interdependence becomes the central fact of political life, not an issue to be shunted to the periphery in the basic question of how to ensure individual autonomy in the inevitable face of collective power. The human interactions to be governed are not seen primarily in terms of the clashing of rights and interests, but in terms of the way patterns of relationship can develop and sustain both an enriching collective life and the scope for genuine individual autonomy ... The constitutional protection of autonomy is then no longer an effort to carve out a space into which the collective cannot intrude, but a means of structuring the relations between individuals and the sources of collective power so that autonomy is fostered rather than undermined' (note 7 above) 8 . In the South African context, the interdependence between individual and community is captured in the spirit of ubuntu. Mokgoro J explains that while 'ubuntu envelops the key values of group solidarity, compassion, respect, human dignity, conformity to basic norms and collective unity, in its fundamental sense it denotes humanity and morality. Its spirit emphasises a respect for human dignity, marking a shift from confrontation to conciliation' Makwanyane (note 9 above) para 308 (Mokgoro J). In Port Elizabeth Municipality v Various Occupiers (note 25 above) the Constitutional Court (Sachs J) 
equal worth of others and the available resources of the society. ${ }^{45}$ But the corollary is a collective acknowledgement that we are diminished as a society to the extent that any of our members are deprived of the opportunities to develop their basic capabilities to function as individual and social beings. ${ }^{46}$ Mokgoro $\mathbf{J}$ expresses this idea in the following passage in the case of Khosa $v$ Minister of Social Development:

Sharing responsibility for the problems and consequences of poverty equally as a community represents the extent to which wealthier members of the community view the minimal well-being of the poor as connected with their personal well-being and the wellbeing of the community as a whole. In other words, decisions about the allocation of public benefits represent the extent to which poor people are treated as equal members of society. ${ }^{47}$

It is implicit in a relational concept of dignity that claims on social resources are strongly justified when people lack the basic material necessities of life to enable them to survive and develop as members of the community. If we are to constitute ourselves as a society that respects human dignity (as we have through the founding values of our Constitution), we are committed to redressing the social and economic conditions of those whose capacity for development and agency is stunted by poverty. By failing to do so, we undermine the very foundations of our new constitutional democracy. ${ }^{48}$

further noted: 'The spirit of ubuntu, part of the deep cultural heritage of the majority of the population, suffuses the whole constitutional order. It combines individual rights with a communitarian philosophy. It is a unifying motif of the Bill of Rights, which is nothing if not a structured, institutionalised and operational declaration in our evolving new society of the need for human interdependence, respect and concern' (para 37, footnotes omitted).

45 In Soobramoney (note 14 above), the Court justified the limitation of the appellant's right to tertiary-level health care services by referring to the state's duty to manage its resources so as to meet the basic needs of others: paras 28, 31 (Chaskalson P), and para 54 (Sachs J). See however the critique of the Soobramoney reasoning by Karin van Marle " No Last Word" Reflections on the Imaginary Domain, Dignity and Intrinsic Worth' (2002) Stell LR 299, 305-7.

46 In an article on the application of the value of human dignity in criminal law, Shannon Hoctor argues that 'dignity has a communitarian aspect: by requiring respect for others' claims to dignity, vindication of the human dignity of all is better assured, and a community of mutual co-operation and solidarity is fostered.' 'Dignity, Criminal Law and the Bill of Rights' (2004) 121 SALJ 265, 315 (footnotes omitted).

47 Khosa v Minister of Social Development 2004 (6) SA 505 (CC) para 74 (footnotes omitted).

48 In the context of unfair discrimination, the Constitutional Court has held that 'the interests of the community lie in the recognition of the inherent dignity of every human being and the elimination of all forms of discrimination' Hoffmann $v$ South African Airways 2001 (1) SA 1 (CC) para 43. In the context of evictions of poor people from their homes, the Court has stated: 'It is not only the dignity of the poor that is assailed when homeless people are driven from pillar to post in a desperate quest for a place where they and their families can rest their heads. Our society as a whole is demeaned when state action intensifies rather than mitigates their marginalisation. The integrity of the rightsbased vision of the Constitution is punctured when governmental action augments rather than reduces denial of the claims of the desperately poor to the basic elements of a decent existence. Hence the need for special judicial control of a process that is both socially stressful and potentially conflictual' Port Elizabeth Municipality v Various Occupiers (note 25 above) para 18. 
The decision in the Treatment Action Campaign case $^{49}$ illustrates the underlying relational concept of human dignity at work. The government was being asked to provide a relatively cheap anti-retroviral drug (Nevirapine) ${ }^{50}$ with a significant potential of reducing the risk of motherto-child transmission of HIV. ${ }^{51}$ While there were additional costs associated with prescribing the drug, particularly the costs of HIVtesting and counselling facilities, the Court found that government had the resources to extend these facilities to hospitals and clinics throughout the public health sector beyond the limited number of test sites. ${ }^{52}$ For the babies of poor women who give birth in the public health sector, this drug has significant life-saving potential. For society to deny poor women and their newborns access to 'a simple, cheap and potentially lifesaving medical intervention, ${ }^{53}$ would clearly indicate a lack of respect for their dignity as human beings entitled to be treated as worthy of respect and concern.

I have sought to illustrate that human dignity derives from the value we ascribe to human beings. Because we value them, we wish to ensure that conditions are created that enable them to develop their capabilities and to flourish as individual and social beings. This encompasses respect for people's diverse identities, their associational freedoms, as well as concern for the material conditions that shape their life choices. Dignity as a value requires respect for people's freedoms, but also helps us to understand why these liberties must sometimes be constrained to protect and nurture the capabilities of others. Finally, I have argued that a relational concept of human dignity best captures the interdependence between individual and social welfare, and also illuminates the circumstances in which people have justified claims to social resources.

In the next section I examine how the value of human dignity can be applied to enrich South Africa's socio-economic rights jurisprudence. I also examine, through my discussion of the Canadian case of Gosselin, ${ }^{54}$ applications of human dignity that can operate to exclude the poor from access to benefits, rather than to facilitate their inclusion.

\section{Human Dignity and its Value in Socio-Economic Rights JURISPRUDENCE}

I have argued for a relational concept of human dignity in which society's neglect to redress conditions of socio-economic disadvantage represents a

49 Minister of Health $v$ Treatment Action Campaign (2) 2002 (5) SA 721 (CC).

50 The manufacturers of Nevirapine had offered to make it available to the South African government free of charge for a period of five years, for the purpose of reducing the risk of mother-to-child transmission of HIV. Ibid para 19, read with paras 71 and 80 .

51 Ibid para 57.

52 Ibid paras $118-120$

53 Ibid para 73.

54 Gosselin v Québec (note 1 above). 
collective failure to value human dignity. This concept helps to challenge stigmatising notions of the poor as 'dependants' of society and as undeserving of social support. ${ }^{55}$ Conditions of poverty are not a reflection of the moral blameworthiness of groups experiencing poverty ${ }^{56}$ rather they reflect how we as a society have failed to value human dignity.

There is another dimension of human dignity that can make an important contribution to the development of our socio-economic rights jurisprudence. This is the concept of the equal worth of people that lies at the heart of human dignity. As the Constitutional Court has affirmed in the context of its equality jurisprudence, the acknowledgment of equal moral worth requires treatment as an equal as opposed to equal treatment. ${ }^{57}$ Treatment as an equal requires full acknowledgement of the racial, gender, social, economic, cultural and other differences between groups in society. Thus the quest for equal worth or dignity is not a quest for uniformity, but a quest to eliminate the disadvantages and inferior status that attach to membership of particular groups. ${ }^{58}$ This substantive approach to equality inevitably requires a contextual analysis which is able to identify the real situations and disadvantages experienced by various groups in the light of our history as well as current social, economic, political and gender relations. ${ }^{59}$

Treatment as an equal demands that we also respond appropriately to the actual needs of differently situated groups. In Harksen v Lane NO, O'Regan $\mathbf{J}$ (in her dissenting judgment) affirms that respect for human dignity in equality jurisprudence requires an approach that is responsive to individual needs and circumstances in order to create a buffer against the construction of further patterns of discrimination:

55 The Constitutional Court has affirmed the close relationship between human dignity and social assistance in Khosa (note 47 above) paras 41 and 52 and in Mashavhav President of the RSA 2004 (12) BCLR 1243 (CC) para 51.

56 On approaches to adjudication in the US premised on notions of the moral blameworthiness of the poor, and the attitude of 'helplessness' in response to their claims, see: T Ross 'The Rhetoric of Poverty: Their Immorality, Our Helplessness' (1991) 79 Georgetown LJ 1499-1547.

57 See R Dworkin Taking Rights Seriously (1977) 227, cited in Prinsloo v Van der Linde 1997 (3) SA 1012 (CC) para 32.

58 As Sachs J states in National Coalition (note 7 above): 'At the heart of the equality jurisprudence is the rescuing of people from a caste-like status and putting an end to their being treated as lesser human beings because they belong to a particular group. The indignity and subordinate status may flow from institutionally imposed exclusion from the mainstream of society or else from powerlessness within the mainstream ...' (para 129). He goes on to affirm that '[e]quality means equal concern and respect across difference' as opposed to uniformity which 'can be the enemy of equality' (para 132).

59 In Brink $v$ Kitshoff NO 1996 (4) SA 197 (CC) O'Regan J refers to the 'deep patterns of disadvantage' which have resulted from gender discrimination in our society, particularly in the case of black women. A 'key message of the Constitution' is that 'all such discrimination needs to be eradicated from our society.' (para 44). In its socio-economic rights jurisprudence, the Constitutional Court has also indicated the reasonableness of the State's measures to realise socio-economic rights must be evaluated in the light of their 'social, economic and historical context': Grootboom (note 10 above) para 43. 
Such patterns of discrimination can occur where people are treated without the respect that individual human beings deserve and particularly where treatment is determined not by the needs or circumstances of particular individuals, but by their attributes and characteristics, whether biologically or socially determined. ${ }^{60}$

Building on this concept of human dignity in equality jurisprudence, dignity as a value in socio-economic rights jurisprudence requires that we take account of the relative urgency of the needs of different individuals and groups and respond correspondingly. ${ }^{61}$ This implies a contextual analysis with regard to the position of particular groups in society and the different order and types of needs experienced by these groups. Thus, for example, one would be required to consider the multifarious ways in which gender relations contribute to women's unequal access to socioeconomic resources. ${ }^{62}$ One would also have to consider the nature of the deprivation and the seriousness of its impact on the affected individuals.

In Watchenuka, the Supreme Court of Appeal held that a consideration of the severe impact of an administrative decision on the socioeconomic circumstances of the applicants was a highly relevant factor. ${ }^{63}$ Thus, while the state could justifiably limit the rights of non-nationals (such as asylum-seekers) to undertake employment and education, different considerations applied when the applicants were destitute. When employment 'is the only reasonable means for the person's support' what is then in issue 'is not merely a restriction upon the

60 Harksen $v$ Lane NO (note 9 above) para 92 (emphasis added). In Canadian equality jurisprudence, human dignity is also central to the determination of discrimination in terms of s 15 of the Canadian Charter of Rights and Freedoms. In Law v Canada (Minister of Employment and Immigration) (1999) 170 DLR (4th) 1 the Supreme Court developed the following understanding of what respect for human dignity in equality jurisprudence requires: 'Human dignity means that an individual or group feels self-respect and self-worth. It is concerned with physical and psychological integrity and empowerment. Human dignity is harmed by unfair treatment premised upon personal traits or circumstances which do not relate to individual needs, capacities or merits. It is enhanced by laws which are sensitive to the needs, capacities, and merits of different individuals, taking into account the context underlying their differences. Human dignity is harmed when individuals and groups are marginalized, ignored, or devalued, and is enhanced when laws recognise the full place of all individuals and groups within Canadian society" (para 53) (emphasis added). In her dissenting judgment in Gosselin (note 1 above) L'Heureux-Dubé J states: 'Prejudicial effects giving rise to a s. 15 claim may result when a legislature simply fails to turn its mind to the particular needs and abilities of individuals or groups so as to provide equal benefit under the law to all members of society' (para 120).

61 See the discussion by Bilchitz of the concept of urgency in protecting people's basic interest in survival and non-impaired functioning: D Bilchitz 'Giving Socio-Economic Rights Teeth: The Minimum Core and its Importance' (2002) 118 SALJ 484, 490-1.

62 Martha Nussbaum argues for the importance of 'an approach that is respectful of each person's struggle for flourishing, that treats each person as an end and as a source of agency and worth in her own right' Women and Human Development (note 4 above) 69. She critiques utilitarian and resource-based approaches to human development as 'insensitive to contextual variation, to the way circumstances shape preferences and the ability of individuals to convert resources into meaningful human activity' (69-70). Particularly in the developing world we need to be 'highly alert' to individual variations of need and the extent to which differently situated individuals can 'convert resources into valuable functionings' (68).

63 Watchenuka (note 43 above). 
person's capacity for self-fulfilment, but a restriction upon his or her ability to live without positive humiliation of degradation'. ${ }^{64}$ To prohibit work and study in these circumstances would normally be unlawful. This requires the Refugee Reception Offices and the Standing Committee on Refugee Affairs to consider carefully the impact on the individual applicant and his or her family of a restrictive condition in relation to work or study.

In its socio-economic rights jurisprudence the Constitutional Court has affirmed that a reasonable government policy must cater for different groups and orders of need in society. ${ }^{65}$ The Court has also taken the critical step of affirming that a government programme that neglects to attend to urgent needs cannot be reasonable. In Grootboom the government's otherwise comprehensive and rational housing programme ${ }^{66}$ was faulted for failing to cater for groups in urgent need:

To be reasonable, measures cannot leave out of account the degree and extent of the denial of the right they endeavour to realise. Those whose needs are most urgent and whose ability to enjoy all rights therefore is most in peril, must not be ignored by the measures aimed at achieving the realisation of the right. It may not be sufficient to meet the test of reasonableness to show that the measures are capable of achieving a statistical advance in the realisation of the right. Furthermore, the Constitution requires that everyone must be treated with care and concern. If the measures, though statistically successful, fail to respond to the needs of those most desperate, they may pass the test. ${ }^{67}$

64 Ibid para 32. In relation to freedom of education, Nugent JA held that when 'a child is lawfully in this country to seek asylum (there might be other circumstances as well) I can see no justification for limiting that right so as to deprive him or her of the opportunity for human fulfilment at a critical period... A general prohibition that does not allow for study to be permitted in appropriate circumstances is in my view unlawful' (para 36, footnotes omitted, emphasis added).

65 Thus in Grootboom (note 10 above), the Court held that a reasonable programme 'must be balanced and flexible and make appropriate provision for attention to housing crises and to short, medium and long-term needs. A programme that excludes a significant segment of society cannot be said to be reasonable' (para 43).

66 Ibid paras 53-54.

67 Ibid para 44 (emphasis added). See also para 52: '[T]here is no express provision [in the Housing Act 107 of 1997] to facilitate access to temporary relief for people who have no access to land, no roof over their heads, for people who are living in intolerable conditions and for people who are in crisis because of natural disasters such as floods and fire, or because their homes are under threat of demolition. These are people in desperate need.' See also TAC (note 49 above): 'The provision of a single dose of Nevirapine to mother and child for the purpose of protecting the child against the transmission of HIV is, as far as the children are concerned, essential. Their needs are "most urgent" and their inability to have access to Nevirapine profoundly affects their ability to enjoy all rights to which they are entitled. Their rights are "most in peril" as a result of the policy that has been adopted and most affected by a rigid and inflexible policy that excludes them from having access to Nevirapine' (para 78). In Port Elizabeth Municipality $v$ Various Occupiers (note 25 above), the Constitutional Court emphasised the importance of taking account of 'the actual situation' of the persons concerned in eviction proceedings: 'In a society founded on human dignity, equality and freedom it cannot be presupposed that the greatest good for the many can be achieved at the cost of intolerable hardship for the few, particularly if by a reasonable application of judicial and administrative statecraft such human distress could be avoided' (para 29). 
The Court has further acknowledged that 'the poor are particularly vulnerable and their needs require special attention'. ${ }^{68}$ Respect for human dignity requires society to marshal its resources and respond strongly to situations in which certain groups are unable to gain access to basic socio-economic needs. The consequences of the deprivation will be severe (either in terms of threats to life or health) and erode the foundations for the further development of people's capabilities. To value human beings as a society demands an appropriate response. The overall resources and capacity of the society concerned will naturally determine this response. But dignity demands that society does its utmost to ensure that those groups who are unable to gain access to basic socio-economic needs are assisted. ${ }^{69}$

This duty is recognised by the United Nations Committee on Economic, Social and Cultural Rights in interpreting States parties' obligations under the International Covenant on Economic, Social and Cultural Rights (1966). According to the Committee '... a State party in which any significant number of individuals is deprived of essential foodstuffs, of essential primary health care, of basic shelter and housing, or of the most basic forms of education is, prima facie, failing to discharge its obligations under the Covenant.' ${ }^{70}$ This places a burden on the state, should it seek to attribute its failure to meet its core obligation to a lack of available resources, to 'demonstrate that every effort has been made to use all resources that are at its disposal in an effort to satisfy, as a matter of priority, those minimum obligations'. ${ }^{71}$

In Grootboom and $T A C$, the Constitutional Court declined the invitation of the amici to base its decision on the concept of a minimum core obligation. In doing so the Court articulated a range of concerns relating to the concept. These included the assumed inflexibility of the minimum core, difficulties in setting minimum standards in the context of varying needs and opportunities for accessing the rights, the lack of institutional competence for determining minimum standards, and the impossibility of giving everyone immediate access to even a 'core'

68 Grootboom (note 10 above) para 36; TAC (note 49 above) para 70.

69 In Khosa (note 47 above), the Court (Mokgoro J) stated: 'The right of access to social security, including social assistance, for those unable to support themselves and their dependants is entrenched because as a society we value human beings and want to ensure that people are afforded their basic needs. A society must seek to ensure that the basic necessities of life are accessible to all if it is to be a society in which human dignity, freedom and equality are foundational' (para 52, emphasis added, footnotes omitted). Nussbaum argues: 'Programs aimed at raising general or average well-being do not improve the situation of the least welloff, unless they go to work directly to improve the quality of those people's lives. If we combine this observation with the thought ... that each person is valuable and worthy of respect as an end, we must conclude that we should look not just to the total or the average, but to the functioning of each and every person. We may call this the principle of each person as end'. Women and Human Development (note 4 above) 56.

70 General Comment 3 (Fifth session, 1990) The Nature of States Parties Obligations (art 2(1) of the Covenant) UN doc. E/1991/23 para 10.

71 Ibid. 
service. ${ }^{72}$ However, properly conceived, the minimum core obligation is neither an absolute duty nor a rigid standard. Rather, it establishes a high threshold of justification when a deprivation of 'essential' levels of socioeconomic goods and services is at issue. The state is required to show that it has exhausted all available methods, and that its resources are "demonstrably inadequate" ${ }^{\text {"73 }}$ to meeting those needs. This raises the central importance of justification in ensuring the strong protection of socio-economic rights. This issue will be revisited in Part $\mathrm{V}$ below.

Thus far I have argued that the value of human dignity can enrich our socio-economic rights jurisprudence, first, by justifying claims against social resources when groups lack the material conditions necessary for the development of their capabilities as human beings. Second, respect and concern for the dignity of each person requires an approach that considers the impact of the deprivation on the actual needs and circumstances of the individuals and groups concerned. Finally, it requires an appropriate response to these conditions. Urgent needs and severe deprivations demand a strong, immediate response. We give expression to the value of human dignity in our constitutional jurisprudence by placing the state under a stringent burden of justification in claims involving a deprivation of basic needs.

However, the use of human dignity in socio-economic rights jurisprudence is not without its pitfalls. As critics have cautioned in relation to South Africa's equality jurisprudence, ${ }^{74}$ there is a danger that human dignity in our socio-economic jurisprudence will result in a focus on subjective personality issues such as the claimants' feelings of self worth and self-respect. This focus can divert attention away from the real issue of the impact of the deprivation on claimants.

The Canadian Supreme Court decision in Gosselin illustrates how differing conceptions of human dignity can influence the outcome of a social benefits claim. ${ }^{75}$ A class action was brought challenging social security regulations in Québec which set the base amount of welfare benefits for adults between the ages of eighteen and thirty years at about one-third of the base amount payable to those thirty years and over. The difference was between $\$ 170$ per month for the younger group and $\$ 466$ per month for the older. The latter was deemed by the legislature to constitute 'the bare minimum for the sustainment of life'. ${ }^{76}$ The only way that those under 30 years could raise their benefits was to participate in various educational and employability programmes. However, for the

72 Grootboom (note 10 above) paras 29-33; TAC (note 49 above) paras 26-39.

73 General Comment 3 (note 70 above) para 11.

74 See Part II above and the works cited there.

75 Gosselin (note 1 above).

76 Ibid paras 251, 285 (Bastarche J) and para 334 (Arbour J). 
majority of young welfare recipients like the appellant participation in these programmes was fraught with difficulties, including restrictive eligibility requirements and the limited number of places available. ${ }^{77}$ The Supreme Court of Canada had to consider whether the challenged regulation violated section 15 (equality right) of the Charter on the grounds that it discriminated on the basis of age. Violations of $\mathrm{s} 7$ of the Charter ${ }^{78}$ and s 45 of the Québec Charter of Rights and Freedoms ${ }^{79}$ were also alleged.

The majority of the Supreme Court found no violations of the Canadian Charter of Rights and Freedoms or the Québec Charter. In regard to $\mathrm{s} 15$, the majority held that a reasonable person in the claimant's circumstances would have perceived the government's positive motives in creating an incentive-based welfare scheme for young people. According to the government this scheme was designed to promote the greater long-term employability of young people. Thus, making welfare payments conditional in this manner did not violate the dignity or human worth of persons under 30 years of age. ${ }^{80}$ This can be contrasted with the more impacts-based approach to human dignity in the dissenting judgment of L'Heureux-Dubé J. After dealing with the practical effects of the regulation on the claimant's ability to meet basic subsistence needs, ${ }^{81}$ she considered whether the claimant would perceive that her dignity had been threatened:

She would have been told that the long-term goal of the legislative scheme was to affirm her dignity. The reasonable claimant would also likely have been a member of the 88.8 per cent who were eligible for the programs and whose income did not rise to the levels available to all adults 30 years of age and over ... The reasonable claimant would have made daily life choices in the face of an imminent and severe threat of poverty. The

77 Thus the government of Québec had only made 30000 programme places available even though 85000 single people under 30 years of age were on social assistance. See Gosselin (ibid) para 283. Four of the dissenting judgments on s 15 raised serious issues about the accessibility of these programmes and questioned whether the regulation was really designed to enhance the long-term situation of those under 30 years as opposed to simply saving money. See, for example, the discussion by Bastarche $\mathbf{J}$ in paras $276-283$ and Arbour $\mathbf{J}$ in para 393.

78 Section 7 of the Canadian Charter provides that: 'Everyone has the right to life, liberty and security of the person and the right not to be deprived thereof except in accordance with the principles of fundamental justice.'

79 Section 45 of the Québec Charter provides that every person in need has a right to 'measures of financial assistance and to social measures provided for by law, susceptible of ensuring such person an acceptable standard of living.'

80 Gosselin (note 1 above) paras 52 - 53, 65 (McLachlin CJC). In Law (note 60 above), the Supreme Court of Canada had held that the key issue in determining whether a distinction conflicts with s 15(1) is whether 'a reasonable person in circumstances similar to those of the claimant would find that the legislation which imposes differential treatment has the effect of demeaning his or her dignity' having regard to the individual's or group's traits, history, and circumstances' (para 60, cited in Gosselin para 25).

81 She found that the regulation in question exposed Ms Gosselin to the risk of severe poverty and in so doing breached her psychological and physical integrity. For example, she pointed out that in 1987 the monthly cost of proper nourishment was $\$ 152$, whereas the guaranteed monthly welfare payment to young adults was $\$ 170$. Gosselin (note 1 above) para 130 . 
reasonable claimant would likely have suffered malnourishment. She might have turned to prostitution and crime to make ends meet. The reasonable claimant would have perceived that as a result of her deep poverty she had been excluded from full participation in Canadian society. She would have perceived that her right to dignity was infringed as a sole consequence of being under 30 years of age, a factor over which, at any given moment, she had no control. ${ }^{82}$

In L'Heureux-Dubé J's judgment, the legislature's good motives did not outweigh the severe impact of the regulation on the claimant's physical and psychological integrity and her human dignity as a member of Canadian society. Her approach to the question whether there was a correspondence between the ground of distinction and the actual needs and circumstances of the affected group is also significant. In this regard, she held that 'there should be a strong presumption that a legislative scheme which causes individuals to suffer severe threats to their physical and psychological integrity as a result of their possessing a characteristic which cannot be changed does not adequately take into account the needs, capacity or circumstances of the individual or group in question' ${ }^{83}$

The approach of the majority in Gosselin to the assessment of whether human dignity had been infringed by the relevant regulation illustrates the dangers of a narrow, 'personality interests'-type approach to human dignity in assessing the constitutionality of a group's exclusion from social benefits. This is further complicated by the introduction of an objective element, focusing not on the actual experiences of the applicant, but on conjecture as to what a reasonable person in the applicant's position would feel. As Sandy Fredman argues, '[t]he reasonable person turns out to be no more than the government's own perception of its policy aims, thus underscoring the deference of the standard of review' ${ }^{84}$ The majority in Gosselin is too deferential to legislative choices that result in a vulnerable group suffering severe deprivation ostensibly to promote the longer-term objectives of greater self-sufficiency and employability among youth on welfare. The minority judgments, by contrast, emphasise the impact on young welfare beneficiaries of the exclusion from a minimally adequate standard of benefits. The infringement of human dignity arises from the fact that the exclusion seriously undermines the physical and psychological integrity of young welfare beneficiaries. This placed a burden on the state to justify the exclusion based on compelling evidence and arguments. The minority concludes that the consequences

83 Ibid para 135 (emphasis added).

84 S Fredman 'Providing Equality: Substantive Equality and the Positive Duty to Provide' paper delivered at the SAJHR Conference, 5-7 July 2004, 11 (forthcoming in (2005) 21 SAJHR part 2). See also G Brodsky 'Gosselin v Québec (Attorney General): Autonomy with a Vengeance' (2003) 15 Canadian J of Women \& the Law 194. 
were of such a severe nature that they could not be justified by the state's long-term objectives. ${ }^{85}$

The minority's approach to human dignity in Gosselin holds the most potential for positively influencing our socio-economic rights jurisprudence. The final section of this paper examines how the value of human dignity can influence our socio-economic rights jurisprudence to make it more responsive to claims for the provision of basic human needs.

\section{Strengthening our Constitutional Response to Basic Needs ClAIMS}

In many respects the evolving jurisprudence on socio-economic rights gives effect to the value of human dignity developed thus far. The Constitutional Court endorses positive state measures to achieve access to socio-economic rights, a context-sensitive evaluation of reasonableness, and the requirement that a reasonable government programme includes short-term relief for those who are in urgent need and are living in intolerable conditions. This applies even if the overall programme is statistically successful in the long term in advancing people's access to socio-economic rights. ${ }^{86}$

The Court's model of review for positive socio-economic rights claims ${ }^{87}$ centres on the reasonableness inquiry. The fundamental question to be answered by the Court in such cases is whether the measures adopted by the state (or the failure to adopt appropriate measures) are reasonable in the circumstances. The reasonableness inquiry is further conditioned by the qualifying phrases in the second subsections of sections 26 and 27, namely the availability of resources and the latitude of

85 Thus, for example, Arbour $\mathbf{J}$ held as follows in considering the s 1 limitation inquiry (having found that the regulation breaches the s 7 rights to life and security of the person): 'it is difficult to accept that denial of the basic means of subsistence is rationally connected to values of promoting the long-term liberty and inherent dignity of young adults. Indeed, the long-term importance of continuing education and integration into the workforce is undermined where those at whom such "help" is directed cannot meet their basic short-term subsistence requirements. Without the ability to secure the immediate needs of the present, the future is little more than a far-off possibility, remote both in perception and in reality.' Gosselin (note 1 above) para 392. This also has resonance with the rationale in Grootboom (note 10 above). Here the government's rational housing programme that was geared to the long-term goal of providing housing for all was nonetheless constitutionally defective for its failure to attend to short-term, urgent housing needs (see notes 64-66 above and accompanying text).

86 Grootboom (note 10 above) paras 44, 68 and see the Court's order para 99.

87 These claims involve two main situations. The first is the exclusion of a particular group from an existing social programme, the second entails the absence of a suitable programme providing access to particular benefits. In the first type of situation, as the Khosa case (note 47 above) illustrates, socio-economic rights and equality claims may often overlap. In the second situation, litigants may rely on the socio-economic rights provisions in the Bill of Rights to argue that the state is under a duty to adopt an appropriate programme 'capable of facilitating the realisation of the right' in question. See Grootboom (note 10 above) para 41 . The absence of a programme catering for the provision of basic needs may also engage the right to equality, particularly in the context of a substantive interpretation of equality. See Brodsky (note 84 above). 
'progressive realisation' afforded the state. ${ }^{88}$ The Court is clearly reluctant to dictate particular policy choices to government. Instead it contemplates in Grootboom that 'a wide range of possible measures' would meet the requirements of reasonableness and thus comply with ss 26 and $27 .{ }^{89}$ It is certainly appropriate that the Court respects the primary role of the democratically elected legislature in relation to socioeconomic policy. The executive also has particular institutional competency to design and implement appropriate policies and programmes. Reasonableness review provides the courts with a flexible, context-sensitive tool for adjudicating positive socio-economic rights claims. ${ }^{90}$

However, its application in relation to claims involving a deprivation of the basic necessities of life is inadequate. The stakes are high for the individuals and groups who approach the courts for relief, entailing threats to life, health and the ability to function in society. I have sought to develop the argument that a failure by society to respond in proportion to the seriousness of the deprivations faced by its members represents a failure to value their fundamental dignity as human beings. In this section I will argue why I believe that the judicial protection of these claims is insufficient, and how it could be improved. Stronger judicial potential of these claims will also signal to the state the constitutional importance of a robust response to situations of severe material deprivation.

One of the shortcomings of the current structure of reasonableness review is that individual litigants bear an onerous burden of proof and persuasion to demonstrate the unreasonableness of government programmes. The Constitutional Court has made it clear that ss 26 and 27 confer no direct entitlement to claim immediate delivery of goods and services from the state, only a right to require government to adopt a reasonable programme. ${ }^{91}$ Thus it is not enough for a group of litigants to approach the Court alleging that they are poor and seriously malnourished, thereby establishing a prima facie violation of the right to food in $\mathrm{s} 27$ of the Constitution. Instead litigants will have to show that the state's actions or omissions are unreasonable in terms of the

88 Grootboom (note 10 above) paras 38, 41, 45-6. Although 'progressive realisation' affords the State the latitude of not requiring immediate realisation of the right, the Court also affirms that it imposes specific obligations on the State to make demonstrable progress in facilitating access to the rights, and in avoiding retrogressive measures: see Grootboom para 45.

89 Ibid para 41.

90 The following key features of a reasonable government programme to realise socio-economic rights were developed by the Court in the Grootboom and the TAC cases: the programme must be comprehensive, coherent, coordinated; it must be balanced and flexible, making appropriate provision for short, medium and long-term needs, and not exclude a significant segment of society; it must include reasonable provision for those in urgent need; it must be reasonably conceived and implemented; it must be transparent, and its contents must be made known effectively to the public.

See Grootboom (note 10 above) paras 39-43; TAC (note 49 above) para 123.

91 Grootboom (ibid) paras 41, 95; TAC (ibid) paras 32-39, and 125. 
second subsection of s 27 . To do so, they will have to review a wide range of government social programmes, and assess their reasonableness in the context of the state's capacity and available resources. ${ }^{92}$ Establishing the unreasonableness of a disparate set of government programmes in the light of the state's available resources will be a matter of great factual and legal complexity which will often be beyond the capacity of indigent and vulnerable groups. ${ }^{93}$ It thus does not facilitate the practical justiciability of this class of claims. ${ }^{94}$

In cases (such as the one discussed above) where people will face irreparable harm through not having their basic needs met, a more appropriate response would be to give the applicants the benefit of a presumption of unreasonableness. The effect would be that prima facie unreasonableness is established when a disadvantaged group shows that it lacks access to the social goods and services that are required to sustain life, health and a basic level of functioning. The burden is then on the state to rebut this presumption with compelling reasons. This presumption would not be dissimilar to that operating in the context of the equality clause, where discrimination on a listed ground is presumptively unfair. ${ }^{95}$ A clear presumption in favour of this category of socioeconomic rights claimants recognises that a social failure to value human dignity is at stake when individuals and groups experience deprivations of subsistence needs. These groups are denied the opportunity to survive and to develop their capabilities. Respect and concern for the value and intrinsic worth of the individuals so afflicted should trigger a presumption of unreasonableness and place a burden of justification on the state.

It should be evident that this approach does not require the setting of inflexible minimum standards of delivery for each socio-economic right.

92 The Court indicated that it would take into account the 'interconnectedness' of rights' in assessing whether the state has fulfilled its obligations: Grootboom (ibid) para 24. Among the measures that the Court indicated would be relevant in relation to access to housing were steps to make the rural areas of the country more viable so as to limit the migration of people from rural to urban areas in search of jobs (para 34). It also indicated that social assistance programmes put in place under s 27 'would be relevant to the state's obligations in respect of other socio-economic rights.' (para 36).

93 See in this regard the submissions of the amici curiae in TAC (the Community Law Centre and IDASA) available at <http://www.communitylawcentre.org.za/ser/docs_2002/ TAC_MTCT_Case_Heads_of_Arguments.doc > para 31.1.

94 The impact of the Court's rejection of the concept of a minimum core obligation on the practical justiciability of socio-economic rights was developed by Wim Trengove SC in representing the amici curiae in the $T A C$ case. On behalf of the amici it was argued that practical justiciability is of particular importance in the enforcement of socio-economic rights because the purpose of these rights is to protect the interests of the poor who lack access to basic amenities of life: 'For most of them, the right of access to court is already a paper right and not a practical reality. The very socio-economic rights designed for their protection and advancement must accordingly not be interpreted in a way that makes enforcement practically impossible' (para 30.2).

95 Section 9(5). 
As the Constitutional Court observed in Grootboom, such an approach would be insensitive to the varying needs and circumstances of differently situated groups in society. ${ }^{96}$ It also does not impose an absolute standard of performance on the state regardless of the social and economic context. However, it does require placing a strong burden of justification on the state in relation to the absence of basic levels of provision for groups living in poverty. ${ }^{97}$

However, given the nature of the deprivations at stake and the seriousness of the consequences for the affected groups, this is not an easy burden to discharge. A rigorous standard of scrutiny is required. In terms of the relational concept of human dignity I have sought to develop, dignity fails to be protected when the standard of justification demanded of government in respect of a failure to fulfil basic needs is low. A response that is not proportionate to the nature of the deprivation and its impact communicates a message that the affected group is not worthy of equal respect and concern. ${ }^{98}$ I suggest two elements of a stricter review standard for this category of claims.

A stricter standard of scrutiny would require a compelling government purpose for failure to ensure that vulnerable groups have access to basic

96 See note 72 above and accompanying text. As Nussbaum argues, 'individuals vary greatly in their needs for resources and in their abilities to convert resources into valuable functionings'. (Women and Human Development, note 4 above, 68). She gives the examples of a pregnant or lactating woman who needs more nutrients than a non-pregnant woman; a child who needs more protein than an adult and a person with paralysed limbs who needs many more resources to achieve the same level of mobility as a person without this disability. See further the discussion at 68-70.

97 See the similar presumption suggested by L'Heureux-Dubé $\mathbf{J}$ in Gosselin (note 1 above).

98 In Khosa (note 47 above), the Court held that 'when the rights to life, dignity and equality are implicated in cases involving socio-economic rights, they have to be taken into account along with the availability of human and financial resources in determining whether the state has complied with the constitutional standard of reasonableness' (para 44). Although not explicitly stated, this suggests a tightening of the review standard in a socio-economic rights case when life, dignity and equality are at stake. In Jaftha (note 12 above), the Constitutional Court held that the relevant provisions of the Magistrates' Court Act 32 of 1944 (permitting sales of execution against people's homes for debt without judicial oversight) rendered people vulnerable to homelessness as they would no longer qualify for housing subsidies. Without such assistance 'they may be rendered homeless and never able to restore the conditions for human dignity' (para 39). The Court accordingly held, in the limitations analysis (s 36), that this constituted 'a severe limitation of an important right' (para 39). The European Court of Human Rights recently held in Connors v United Kingdom Application 66746/01 (judgment of 27 May 2004) that the eviction of a gypsy family from a council-owned site constituted a serious interference with their right to respect for their 'private and family life' and their home in terms of art 8 of the European Convention of Human Rights (1950). The Court observed that art 8 'concerns rights of central importance to the individual's identity, self-determination, physical and moral integrity, maintenance of relationships with others and a settled and secure place in the community' (para 82). The consequence of the eviction was homelessness for the family 'with the adverse consequences on security and well-being which that entails' (para 85). These serious consequences warranted, in the Court's opinion, 'particularly weighty reasons of public interest by way of justification'. In these circumstances, 'the margin of appreciation to be afforded to the national authorities must be regarded as correspondingly narrowed' (para 86). 
needs. Competing state priorities and resources-based justifications often give the courts the most difficulty as they raise issues of separation of powers and institutional competence. ${ }^{99}$ However, respect for the dignity of human beings requires a serious engagement with these justifications. It is not sufficient to simply assert, as the Court did in $T A C$, that, '[i]t is impossible to give everyone access even to a "core" service immediately'. ${ }^{100}$ The state should at least be required to establish the factual underpinnings of its justifications based on resources. ${ }^{101}$ There are different formulations of the threshold to be met concerning resourcebased justifications for limiting access to constitutional rights. For example, the UN Committee on Economic, Social and Cultural Rights requires states to show that their resources for meeting basic needs are 'demonstrably inadequate' in the context of other equally important government purposes. $^{102}$ In Eldridge $v$ British Columbia (Attorney General), ${ }^{103}$ the Canadian Supreme Court held that s 15(1) (equality) imposed positive duties on the government to ensure 'reasonable accommodation' of disadvantaged groups in government programmes to the point of 'undue hardship'. ${ }^{104}$

Whatever formulation is adopted, courts should scrutinise the state's evidence and arguments closely with a view to assessing whether they constitute a compelling justification in the context of current South African society for failing to provide basic needs. The state is not necessarily required to show the diversion of all resources to the provision of basic needs. Ideally basic needs claims should be addressed in the context of integrated social programmes as opposed to ad hoc, crisis

99 See, for example, TAC (note 49 above): 'It should be borne in mind that in dealing with such matters the courts are not institutionally equipped to make the wide-ranging factual and political enquiries necessary for determining what the minimum-core standards ... should be, nor for deciding how public revenues should most effectively be spent' (para 37).

100 Ibid para 35 .

101 In the context of the positive duties imposed by civil and political rights such as the right to vote, the courts have required that the factual basis for justifications based on logistics and costs be established by the state in the context of a limitations enquiry: Minister of Home Affairs $v$ National Institute for Crime Prevention (NICRO) 2005 (3) SA 280 (CC) paras 47-51.

102 See notes 70 and 71 above and the accompanying text.

103 (1997) 151 DLR (4th) 577 (SC). The Court was faced with a challenge to the failure of the Medical Services Commission of British Columbia to provide sign language interpretation for deaf patients in the health system. It held that this omission constituted a prima facie violation of their right to equal benefit of the law without discrimination under s 15(1) of the Charter.

104 Ibid paras 77-80. In response to the government's argument in the s 1 (limitations) analysis that the appellants' claim would have 'a ripple effect throughout the health care field, forcing governments to spend precious health care dollars accommodating the needs of a myriad of disadvantaged persons' (para 91), the Court held as follows: 'The respondents have presented no evidence that this type of accommodation, if extended to other government services, will unduly strain the fiscal resources of the state. To deny the appellants' claim on such conjectural grounds, in my view, would denude s 15(1) of its egalitarian promise and render the disabled's goal of a barrier-free society distressingly remote' (para 92). 
interventions. ${ }^{105}$ Sometimes, however, temporary solutions may be essential to respond to individual needs until the groups can be catered for within mainstream programmes. What should be required is evidence that the state is taking concrete and well-targeted budgetary and other measures to address effectively the situation of those who are experiencing severe deprivations of basic needs. Despite the above statement in the $T A C$ case, the Court, in fact, carefully analysed the state's resource-based justifications for the failure to extend the provision of Nevirapine throughout the public health sector and concluded that they were unconvincing. ${ }^{106}$ The Court's decision in Khosa also illustrates that it is both willing and able to engage vigorously with the state's resource-based justifications for failing to fulfil socio-economic rights. ${ }^{107}$

The second element of a strengthened review standard concerns the inclusion of a more rigorous proportionality analysis. ${ }^{108}$ The Court comes close to a proportionality test by establishing, as an important factor in the reasonableness enquiry, whether the state has made provision for those in immediate need. As Danie Brand argues, the Court 'leans significantly closer [to a proportionality test] by incorporating such an element into its standard of scrutiny, narrowing the range of policy options that it would be legitimate for government to choose from and thinking about the relative efficiency of different policy options. ${ }^{109}$ In $T A C$, the Constitutional Court required government to adopt a particular policy, namely the provision of Nevirapine (or any other equally appropriate or better method) throughout the public health sector for the prevention of mother-to-child transmission of HIV. This was unavoidable given the fact that there was in fact very little scope for a range of policy choices. Without the provision of Nevirapine (or a similar anti-retroviral drug), large numbers of infants would continue to be infected with HIV and die prematurely as a result of mother-to-child transmission. Where the state does have a legitimate range of policy choices to respond to basic needs claims it would be appropriate for the Court to give the legislature and executive the first opportunity to design an appropriate programme. However, this could be achieved at the

105 As the Constitutional Court observed in Grootboom (note 10 above), a reasonable programme 'must be balanced and flexible and make appropriate provision for attention to housing crises and to short, medium and long term needs' (para 43).

106 See notes 49-53 above and accompanying text.

107 Khosa (note 47 above) paras 60-62 (the inclusion of permanent residents in the social grants system 'will be only a small proportion of the total cost').

108 Theunis Roux observes that although the reasonableness test 'undoubtedly requires the court to substitute its view of what the constitution requires - the inclusion of the excluded group for that of the political branches', it 'stops short ... of a full-blown proportionality test'. T Roux 'Legitimating Transformation: Political Resource Allocation in the South African Constitutional Court' (2003) 10 Democratization 92, 97.

109 D Brand 'The Proceduralisation of South African Socio-Economic Rights Jurisprudence, or "What are Socio-Economic Rights For?" in Botha et al (eds) (note 15 above) 33, 41. 
remedial stage and should not preclude a finding that government has failed to fulfil its positive duties. ${ }^{110}$

The inclusion of a more explicit proportionality analysis should include a requirement that government show that there are no less restrictive means of achieving its purposes than a total denial of access to basic socio-economic goods and services. ${ }^{111}$ This should also entail showing that it has taken steps to mitigate the harm suffered as a result of the deprivation. Mitigating measures are particularly important when the provision of even basic levels of services to all who need them is unattainable in the short term. The situation of these groups must remain a matter of high priority and programmes aimed at alleviating the worst impact of the deprivations experienced must be put in place. ${ }^{112}$ In addition, the state must show that it is monitoring the deprivation of basic needs, and devising programmes and strategies for remedying the situation within the shortest possible period of time. ${ }^{113}$

In many respects, this inquiry resembles the limitations inquiry under s 36. This is a consequence of the model of reasonableness review adopted by the Court for measuring compliance with the state's positive obligations under ss 26 and 27. In the Khosa case, the Court alluded to the 'difficulty in applying section 36 of the Constitution to the socio-

110 This could be facilitated through the use of the remedy of supervisory jurisdiction, which is discussed further below.

111 Currie and De Waal describe this element of the proportionality analysis as follows: 'The limitation will not be proportionate if other means could be employed to achieve the same ends that will either not restrict rights at all, or will not restrict them to the same extent. I Currie and J De Waal The Bill of Rights Handbook 5 ed (2005) 183-4. In Eldridge (note 103 above), the Canadian Supreme Court held, in its s 1 (limitations) enquiry, that the government had 'manifestly failed to demonstrate that it has a reasonable basis for concluding that a total denial of medical interpretation services for the deaf constituted a minimum impairment of their rights'. (para 87). The Ministry of Health had decided not to fund the interpretation programme even in part. In this regard, the Court held: 'Other options such as the partial or interim funding of the program offered by the Western Institute for the Deaf and Hard of Hearing, or the institution of a scheme requiring users to pay either a portion of the cost of interpreters or the full amount if they could afford to do so, were either not considered or were considered and rejected' (para 93).

112 In General Comment No 3 (note 70 above), the UN Committee on Economic, Social and Cultural Rights emphasised that 'even where the available resources are demonstrably inadequate, the obligation remains for a State party to strive to ensure the widest possible enjoyment of the relevant rights under the prevailing circumstances' (para 11). It goes on to highlight the continuing obligation to protect the poor even during periods of resource scarcity: 'Similarly, the Committee underlines the fact that even in times of severe resource constraints whether caused by a process of adjustment, of economic recession, or by other factors the vulnerable members of society can and indeed must be protected by the adoption of relatively low-cost targeted programmes' (para 12).

113 The UN Committee on Economic, Social and Cultural Rights has adopted the view that the State's duties 'to monitor the extent of realization, or more especially of the non-realization, of economic, social and cultural rights and to devise strategies and programmes for their promotion, are not in any way eliminated as a result of resource constraints'. General Comment 3 (note 70 above) para 11. 
economic rights entrenched in sections 26 and 27 of the Constitution'. ${ }^{114}$ The Court held that it was not necessary to decide the issue of whether 'a different threshold of reasonableness' is called for in ss 26 and 27 than is the case in section $36 .{ }^{115}$ An advantage of conducting the inquiry into the justifiability of the state's acts or omissions in terms of the general limitations clause (s 36) is the requirement of a law of general application. This has the important benefit that limitations on people's access to basic needs would have to be publicly debated and adopted by the elected representatives of the people. ${ }^{116}$ However, if the internal limitations in sections 26(2) and 27(2) are going to do the major work in assessing the state's compliance with its positive duties, the inquiry should encompass a high standard of justification, including a more rigorous proportionality analysis, at least in respect of basic needs claims.

The standard of scrutiny may vary in intensity, depending on the nature of the interests at stake. A strict level of judicial scrutiny is appropriate when a case concerns the claimants' inability to gain access to the resources needed to survive and participate in society. ${ }^{117}$ This strict form of scrutiny should not be triggered only in emergency or crisis situations. The Court in Grootboom also referred in its order to those 'living in intolerable conditions'. ${ }^{118}$ This clearly contemplates a broader set of circumstances than emergencies. In insisting on the strong judicial protection of basic survival needs, we should not lose sight of the fact that we are concerned not only with physical survival, but with the essential material conditions that each person needs to develop his or her capabilities and to function effectively as a member of society. This includes the physical, psychological and social dimensions of an individual's personhood. ${ }^{119}$ The standard of review can be progressively relaxed when claims are made to levels of social provisioning that are less closely related to people's ability to survive and function effectively in

114 Khosa (note 47 above) para 83 . See also the academic commentaries cited by the Court in note 88 of the judgment.

115 Ibid para 84 . For a recent view on the relationship between the internal limitations in ss 26 and 26 and the general limitations clause in s 36, see K Iles 'Limiting Socio-Economic Rights: Beyond the Internal Limitations Clauses' (2004) 20 SAJHR 448.

$116 \mathrm{It}$ is noteworthy that in respect of the negative violation of the duty not to deprive people of existing access to socio-economic rights the Constitutional Court has now held in Jaftha (note 12 above) that justification is appropriately considered in terms of the general limitations clause. See paras 31 to 34 .

117 David Bilchitz refers to people's basic or 'urgent' interest 'in being free from threats to one's survival, being free from severe physical suffering, and not being exposed to serious health risks that impair one's ability to act'. 'Giving Socio-Economic Rights Teeth: The Minimum Core and its Importance' (2002) 118 SALJ 484, 490. He argues that the urgency of the interests at stake justify strong judicial protection (491).

118 Grootboom (note 10 above) para 99.

119 See the discussion of Nussbaum's list of 'central human capabilities' in notes 26 to 29 above and accompanying text. Bilchitz (note 117 above) 490 also refers to people's more extensive interest 'in living in an environment that is conducive to their flourishing and development on physical, emotional and mental levels'. 
society. This graduated standard of review is accommodated by the concept of 'progressive realisation' in ss $26(2)$ and 27(2). ${ }^{120}$ Thus, while a stronger standard of review is justified for basic needs claims, it may be appropriate to allow the state greater latitude (in terms of both time and resource allocation priorities) when the claim involves more tertiary levels of provisioning. In the case of children, material deprivation can have a profound impact on the future development of their basic capabilities, calling for heightened scrutiny of the impact of such deprivations. ${ }^{121}$

The final area in which the Court could strengthen its constitutional response to socio-economic rights claims is in the field of remedial jurisprudence. A detailed discussion of this aspect is beyond the scope of the present paper. However, it is evident that the nature of the urgent interests at stake in the socio-economic rights claims that are the focus of this paper demands an appropriate and effective remedy. The orders handed down in cases such as $T A C$ will ultimately result in the extension of critical benefits to significant numbers of people. ${ }^{122}$ However, the Court has indicated that a finding that a government programme is unreasonable will not necessarily imply that all in desperate need should receive relief immediately. ${ }^{123}$ Nonetheless, as the Court indicated in $T A C$, '[e]very effort must, however, be made to do so as soon as reasonably possible'. ${ }^{124}$ There will be situations where it would be impossible to remedy immediately a situation that has been found to be in violation of ss 26 and 27, or where the granting of relief only to the litigants before the court would be inequitable to other similarly situated groups. The courts' broad power to make 'any order that is just and equitable'125 provides the remedial flexibility to make appropriate orders in these situations. However, one should never lose sight of the fact that there are serious interests of human survival and dignity at stake. The language of the orders handed down by the courts should reflect this fact, and signal

120 See the discussion of the Court's interpretation of 'progressive realisation' in Liebenberg (note 13 above) ch 33, 41-42.

121 The drafting of s 28(1)(c) of the Constitution suggests a stronger standard of scrutiny for children's socio-economic rights. Prima facie, children are guaranteed a basic level of socioeconomic rights, with limitations to this entitlement falling to be determined in terms of the general limitations clause (s 36). For a critical evaluation of the Court's approach to the interpretation of children's socio-economic rights, see Liebenberg (note 12 above) ch 33, 4852.

122 This, of course, assumes that the state diligently executes the Court's orders and that there is effective monitoring and advocacy in respect of the implementation of the orders by institutions such as the SA Human Rights Commission, the press and non-governmental organisations. On the efforts of the Treatment Action Campaign in seeking to ensure the implementation of the TAC order, see M Heywood 'Contempt or Compliance: The TAC Case After the Constitutional Court Judgment' (2003) 4 ESR Review 7.

123 Grootboom (note 10 above) para 69; TAC (note 49 above) para 125.

$124 T A C$ (note 49 above) para 125.

125 Section 172(1)(b) of the Constitution. 
the requirement that the state remedy the defect 'diligently and without delay'. ${ }^{126}$ This is exemplified in the mandatory nature of the order handed down in $T A C$ combined with the duty to take the steps specified in the order 'without delay'. ${ }^{127}$ When it is not inappropriate or unjust, the courts should also seriously consider granting individual remedies to the successful litigants. ${ }^{128}$ This reflects the value we should place on the dignity of each person.

The $T A C$ order has been criticised for its failure to grant the supervisory order sought by the applicants. ${ }^{129}$ While the Constitutional Court accepted that such orders could be given in appropriate circumstances, it indicated that that they should generally not be made in those terms 'unless this is necessary' to secure compliance with a court order. ${ }^{130}$ The Court went on to express its faith that the government would respect and execute its orders. However, an equally important consideration, as Geoff Budlender has suggested, 'is the risk of severe consequences (such as the loss of life)' in the event of a failure by the government to comply with its obligations. ${ }^{131} \mathrm{In}$ cases where severe economic deprivation threatens people's lives and capacity for future development, this fact should weigh heavily with a court in considering a supervisory order. This is particularly the case where the breach cannot be remedied by a single action ${ }^{132}$ but requires a series of structural reforms and administrative actions taken over a period of time. ${ }^{133}$ Finally, if there is a range of policy options for responding to basic needs claims (as in the Grootboom situation), the remedy of supervisory jurisdiction can be formulated to allow the state to select the appropriate policy while retaining judicial supervision in respect of the constitutionality of the policy choice and its implementation. In this way, a supervisory remedy may be crafted that respects the roles and competencies of the legislature and executive without abdicating judicial responsibility for the enforcement of socio-economic rights. ${ }^{134}$

126 See s 237 of the Constitution.

127 TAC (note 49 above) para 135. The Grootboom order has been criticised for its purely declaratory nature and the impact this had on the slow implementation of the order: see $\mathrm{K}$ Pillay 'Implementation of Grootboom: Implications for the Enforcement of Socio-Economic Rights' (2002) 6 Law, Democracy \& Development, 255.

128 As the Court pointed out in August (note 9 above) para 30: 'We cannot deny strong actual claims timeously asserted by determinate people because of the possible existence of hypothetical claims that might conceivably have been brought by indeterminate groups.'

129 See D Bilchitz 'Towards a Reasonable Approach to the Minimum Core: Laying the Foundations for Future Socio-economic Rights Jurisprudence' (2003) 19 SAJHR 1, 23-26. The High Courts in both the Grootboom and TAC cases handed down supervisory orders: Grootboom v Oostenberg Municipality 2000 (3) BCLR 277 (C) 293H-294C; Treatment Action Campaign v Minister of Health 2002 (4) BCLR 356 (T) 386I-384H.

130 TAC (note 49 above) para 129.

131 G Budlender 'Access to Courts' (2004) 121 SALJ, 358.

132 For example, the 'reading in' remedy granted in the Khosa case (note 47 above) to cure the omission of permanent residents from the Social Assistance Act 59 of 1992 (para 98).

133 See: W Trengove 'Judicial Remedies for Violations of Socio-Economic Rights' (1999) 1, 9-10.

134 See, for example, City of Cape Town v Rudolph 2004 (5) SA 39 (C). 


\section{CONCLUSION}

At the core of the value of human dignity lies the injunction to respect the intrinsic worth of all human beings. Drawing on Nussbaum's work, I have argued that we value human beings by viewing them in the context of the reality of their lives and inquiring what they are actually able to be and to do. Through this inquiry we are confronted with the importance of social power relations and material conditions for people's ability to survive and develop their capabilities as individual and social beings.

To constitute ourselves as a society that values human dignity we must develop appropriate responses to conditions of disadvantage and material deprivation in social policy and constitutional adjudication. In constitutional adjudication this requires a focus on the actual impact of the state's actions or omissions on the life chances of disadvantaged groups. It also demands a proportionately urgent response to conditions that undermine people's ability to survive and develop their capabilities. This is promoted by placing a strong burden of justification on the state in claims where a deprivation of access to basic human needs is at stake. This approach does not advocate a two-tier standard of review based on a rigid distinction between 'core' and 'non-core' needs. If minimum core obligations are conceived as universal, abstract and a-contextual standards of state provision, they will certainly be unjust to a range of groups who do not fit the background norms and conditions that inform the setting of these standards. Instead, what is envisaged is a continuum of judicial scrutiny of the state's justifications informed by a contextual, evolving assessment of the position of the claimant group in society, the nature of the resource or service to which access is sought, and the impact of the denial of such access on the affected group.

In many respects the Constitutional Court's evolving jurisprudence on socio-economic rights promotes the contextual, relational concept of human dignity developed in this paper. However, our constitutional response to claims of material deprivation could be strengthened, and I have suggested how this could be accomplished within the Court's model of reasonableness review and remedial jurisprudence.

A society characterised by stark inequalities and deep poverty is most in peril of failing to value the human dignity of the poor. The role of the Constitutional Court is to hold us accountable to the vision we articulated when we adopted our Constitution so as to, as the Preamble declares, '[i]mprove the quality of life of all citizens and free the potential of each person'. 